\title{
高分子分離膜による農薬除去
}

佐々木崇夫

\section{Removal of Pesticides by Polymer Membranes}

Takao SASAKI

Abstract: Nanofiltration membranes attract attention to take a role of the high performance purification of water. The purification processes with a little energy consumption are enabled by the selection of membrane materials and driving conditions.

\section{1.はじめに}

残留農薬や医薬品が水源である河川や湖沼の水に混入す ると, 安全・安心な飲み水の確保には頭の痛い課題とな る。農薬類は水質管理目標設定項目として管理され, 今年 4 月からは 102 項目に追加された。微量であ生体への影響 が大きく難分解性であることが強く認識されている。

\section{2. 高度净水処理技術}

水中の残留農薬を取り除く手法はオゾン・活性炭処理が 知られている。オゾンは酸化反応で農薬を分解できる反 面, 副成物の残留が懸念される一方, 逆浸透 $(\mathrm{RO})$ 膜やナ ノろ過 $(\mathrm{NF})$ 膜を用いた高分子膜分離法は水中の物質を物 理的に分離できるので有害副成物が発生しないクリーンな 方法である。北米やヨーロッパでは NF 膜の導入が進み, メリーショワーズ浄水場（仏）では 14 万 $\mathrm{m}^{3} /$ 日（約 50 万 人分）の処理設備が稼働している。

\section{NF 膜による有機物除去}

$\mathrm{NF}$ 膜は分子量数百の分子や二価イオン, 重金属などの分 離に適した膜で, 上水製造 (水の浄化)ではトリハロメタン 前駆物質や農薬, 硬度成分なよ゙が除去対象となる。NF 膜を 用いた有機物の除去に関する研究 ${ }^{1}$ は多く，除去性能に影響

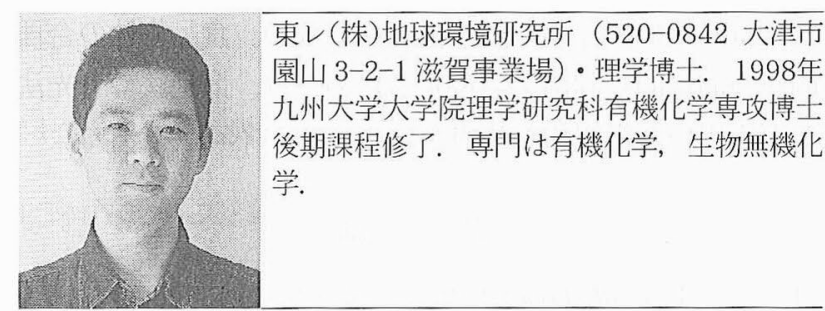

Table 1. Pesticide rejection of UTC-20, UTC-60, UTC-70L

\begin{tabular}{cccc}
\hline \hline & UTC-20 & UTC-60 & UTC-70L \\
\hline Flux $\left(\mathrm{m}^{3} / \mathrm{m}^{2} / \mathrm{d}\right)^{*}$ & 1.23 & 1.22 & 0.55 \\
\hline Rejection $(\%)$ & & & \\
$5 \mathrm{ppb}$ simazine & 88.1 & 36.7 & $98.6^{* *}$ \\
$5 \mathrm{ppb}$ simazine & 78.5 & 52.5 & - \\
$\quad+100$ ppm NaCl & & & \\
5 ppb atrazine & 94.9 & 86.1 & 98.8 \\
\hline
\end{tabular}

Test Condition: $0.54 \mathrm{MPa}, \mathrm{pH} 6.5,25^{\circ} \mathrm{C}$

*500 ppm NaCl, **40 ppb simazine

を与える因子についてさまざまな報告がなされている。

ポリアミド NF 膜のUTC-20, UTC-60 はそれぞれカチ オン性, アニオン性膜である。Table 1 にUTC-20, 60 と 低圧 RO 膜 UTC-70L の農薬の除去性能を示した。農薬は 除草剂シマジン (分子量 202) とアトラジン (同 216) を用 いた。NF膜は Flux（膜透水量）が大きく除去率は UTC20 のほうが UTC-60 よりも高い。農薬に対する膜の荷電 特性や緻密性に由来すると考えられる。シマジンの除去率 は共存する塩によって変化し, 電解質が存在することで膜 荷電の影響が減少して正荷電性の UTC-20 では除去率低 下, 負荷電性の UTC-60 では除去率が向上したと考えられ る。水源の特性に応じて運転条件を設計し，よりエネル ギー消費の少ない上水製造が可能となる。低圧 (0.3 MPa) で運転可能な高性能 NF 膜2を含め, 今後も農薬, 医薬品な どの有機物除去に適した NF 膜が開発されると思われる。

\section{文献}

1) H.-A. Kim, J.-H. Choi, S. Takizawa: Separation and Purifcation Tech., 56, 354 (2007)

2) Y. Fusaoka, T. Inoue, M. Murakami, M. Kurihara: Proc. AWWA Membrane Technology Conference, San Antonio, TX, United States (2001) 